\title{
"Inoculations: The Social Politics of Time, Labor, and Public Good in COVID-America"
}

\author{
Jennifer Klein
}

\author{
"We are becoming a 24/7 workforce." \\ -Fair Workweek Initiative \\ "I Can't Breathe" \\ -Eric Garner, George Floyd, Manuel Ellis, Derrick Scott, Byron Williams, \\ Vincente Villela, Ngozi Mbegu, Willie Ray Banks, James Brown...1
}

On May 1, 2020, Justa Barrios, a New York City home-care worker and labor activist, passed away from COVID-19. After working twenty-four-hour shifts for fourteen years, Barrios had injuries and compounding medical issues, including asthma, stomach difficulties, and heart problems. Her doctor determined that she could no longer work twenty-four-hour shifts. Yet when the homecare agency received a letter from the doctor requesting Barrios be assigned to eight-hour shifts, the agency dropped her. Barrios fought back. She found her voice in the "Ain't I a Woman?!" Campaign; comrades described her as a "fearless leader." Stemming from an alliance among female immigrants and US-born garment, plastics, office, and home-care workers, via workers' centers such as the National Mobilization Against Sweatshops, this organizing effort has sought to end twenty-four-hour days-and the legally permissible practice of paying for only thirteen hours - in New York state through direct action, the courts, union arbitration, and state legislation prohibiting twentyfour -hour shifts. Women such as Justa Barros, Lai Yee Chan, Mei Kum Chu, Seferina Rosario, and Sileni Martinez see the "Aint I a Woman?!" Campaign as a "new women's movement fighting for control over our time, health, respect and payment." As a cross-racial group, members chose to invoke Sojourner Truth, who tied together the causes of slavery abolition and women's rights, emancipation from coerced labor and from patriarchy, the dignity of women's labor and the dignity of release from work. But this legislation, which would seem so obviously humane and jarringly anachronistic, has been stalled in the New York legislature and ignored by Governor Andrew Cuomo for over a year. ${ }^{2}$

Then, in March 2020, the rapid onset of the COVID-19 pandemic in New York translated into both intensified health risks and expectations for longer hours off the clock for nursing home aides and home-care workers. The fear spawned by precarious jobs doubled into fear of deadly exposure, "Ain't I a Woman" thus expanded demands to the Cuomo Administration to include PPE, regular testing, and safe transportation. ${ }^{3}$ 
Owing to an extraordinary convergence of two distinct forms of violence and risk - a novel pandemic and the exposure of the systematic violence of the state through policing - the US working class has become visible as $a$ class. COVID-19 became one more assault added onto the lives of Black Americans. Policing, as a class project, is about disciplining the poor, making sure they're not disrupting the decorum of public space-they're either at work or unseen, not there, constricted, pushed out. The police secure the city for the worthy and deserving and purge public space of the undeserving. Policing and surveillance perpetuate the devaluation of Black bodies in particular spaces: spaces of consumption, leisure, and residence. Black Lives Matter is by necessity a class struggle. Breonna Taylor worked as an emergency room technician and had done four overnight shifts at the hospital just before she was killed by a police invasion while she slept. ${ }^{4}$ The convergence brought to the fore what have been fundamental issues of the working class for over two centuries: bodily safety and health; community well-being; repression through violence workers of the state (police, state militias, national guard); the attempt to recapture time from the boss; and the redistribution of power.

The coronavirus pandemic spread through the United States amid an historical phase characterized by the shattering of predominant liberal "work time" norms. Capitalism, from its inception, has always entailed the appropriation, restructuring, and domination of time. The wage contract cedes to the employer the prerogative to shape how workers' bodies and energies and capacities will be used. The pressures of competition, the logic of accumulation, and the drive for cheaper production impelled capitalists to take over and master time - that of the worker-producer, the shop, and the transport of goods. The ability to extract value depended on the ability to control time. As people became dependent on the market for survival, individuals and families lost control not only over what constituted work time but also over their ability to allocate time between wage work and other aspects of their lives. Along with abolitionism, the Eight-Hour Day movement became one of the powerful, transnational mass movements of the nineteenth century, calling for time, dignity, and emancipation. The simple elegance of its declaration-"Eight Hours for Work, Eight Hours for Rest, Eight Hours for What We Will" entailed profound claims. Shorter hours with just recompense had to be accompanied by rights: wages that would provide sustenance for physical comfort and health; a right to participate in the market without degradation; and the time and opportunity for political and social well-being, including family time, education and intellectual development, civic or religious involvement, leisure and recuperation, or designing revolution. Both female and male proponents believed long hours would have a debilitating effect on the nation's polity and culture. $^{5}$

The New Deal and mass industrial unionism changed the division or arrangement of time as part of the project to extend democracy to the workplace and security for those with or without work. Industrial democracy entailed the social pooling of risk, democratization of power, and due process on the job. 
Security required collective power and a working-class challenge to corporate titans. $^{6}$ In the United States, Fair Labor Standards Act (FLSA), Social Security Act, and National Labor Relations Act (NLRA) finally institutionalized the long struggle for the eight-hour day. Unemployment insurance and old age pensions were built upon the assumed normativity and desirability of the eight-hour day and forty-hour work week. After World War II, "the push to shorten work time and to gain more control over time found new expression in efforts to gain a shorter work year and a shorter work life," according to Dorothy Sue Cobble. That effort took the form of paid vacations, paid holidays, paid sick leave, and retirement pensions. It ignored women's demands for a shorter working day, since they had to work a second shift at home. ${ }^{7}$

At the same time, New Deal labor laws embedded new forms of social stratification. The formal classification of "employee" became the gateway to these benefits. They also specifically excluded service occupations and sectors that employed predominantly women, African Americans, and Latinos. From the late 1940s-1970s, much of the political economic struggle aimed to widen the coverage of labor rights and social security to those who had been left in the margins. In the words of the Union of Hospital and Health Care Employees Local 1199, their fight to win inclusion in the FLSA, NLRA, and Social Security was a campaign for civil rights and "first-class citizenship."

The coronavirus pandemic of 2020 and its attendant economic crises hit the United States as the last structural vestiges of New Deal labor standards were petering out. Antilabor employers and conservatives had devised mechanisms that subverted the functioning of the National Labor Relations Board, turning it into labyrinth that could stymie and derail unionization campaigns and decertify existing unions. Union membership in the United States has been in steady free-fall since the late 1970s, with courts, management consultants, personnel departments, Republicans, conservative think tanks, and lobbyists arrayed against them. State legislatures allowed both the tax rate and the collection of unemployment compensation taxes to lag and unemployment funds ended up the red. The disaggregation of the eight-hour day and fortyhour work week hastened this outcome. The dissipation of organized worker power enabled American workplaces to once again become insular spaces shielded from independent or external health and safety inspections.

American business developed a new mode of operation to utterly fragment the employer-employee relation upon which "industrial democracy" was premised: the temp industry. Beginning at first, in the 1960s, as an agency service providing supplemental office or retail work done by women during seasonal high points, temp agencies pushed their way into myriad labor markets across the economy over the following decades, providing everything from dental hygienists, custodians, accountants, paralegals, writers, editors. ${ }^{8}$ Eventually, entire job categories were permanently subcontracted out, resulting in what David Weil has called "the fissured workplace," where it appeared that no one was really in charge of labor conditions. For the supplier or franchisee at the bottom of the labor supply chain, the labor costs were the only variable. 
So they had to slice and dice labor time to gain the extra profit margin. The parent company thus used high turnover to its advantage, churning out those at the bottom. In the final decades of the twentieth century, widening circles of American workers became excluded from the legal classification and protection of "employee," with almost a third of the American workforce no longer covered by the FLSA."

Temp agency employment and the fissured workplace shook the foundations of the eight-hour day, the standard work week, the coverage of the NLRA and FLSA, and the welfare state. Temp agencies themselves aggressively worked to eviscerate the income support that linked employment and the welfare state. Evading workers' compensation and unemployment claims became a particular expertise of theirs. Temp agencies disputed such claims persistently and with success, using the courts to subvert statutory benefits. Being able to appear in court posed enormous and costly barriers for precarious workers. Further, the industry lobbied to influence labor law-such as the laws that denied temps' claims for unemployment insurance. ${ }^{10}$

On the flip side of underemployment, mandatory, forced overtime became a common practice. More than one in five workers in the United States is forced to work overtime, a practice steadily on the rise in the decade leading up to the COVID-19 pandemic. Regular mandatory overtime added, on average, almost ten hours a month to work schedules. Nurses at major hospitals had to do two shifts of overtime on top of their regular ones. Working in a factory, call center, or warehouse, bathroom breaks were not allowed. ${ }^{11}$ When workers have little control over time, their exposure and susceptibility to risks rise.

Subcontractors are often paid low wages and receive minimal or no health care. In these cases, workers experienced "pay or workplace conditions that violate one or more workplace laws." In fissured industries, violations included off-the-clock work, unpaid overtime, and failure to pay minimum wage. ${ }^{12}$ Yet, studies by the National Employment Law Project, have found that "more than 60 million workers in the U.S. cannot sue their employers[who break the law] due to forced arbitration clauses, with women, people of color, and lowwage workers disproportionately impacted." Forced arbitrations prevented workers earning less than $\$ 13$ from recovering $\$ 12.6$ billion in stolen wages in $2019 .^{13}$

The logical extreme of this instability was reached with the technological revolution of the platform economy: the app-based income earning activities of UBER, Task Rabbit, Fiverr, and Instacart. Through these task service brokers, people used their own cars and tools to provide one-time and quick services directly to individuals. There was no workplace, no boss, and often only a race to the bottom bidding for work. There were unending hours of work but not enough work. The precarity of temp and low-paid part-time work had already driven many to use these apps. They now tried to cobble together a living in the app economy, working as much as seven days a week, hustling to assemble a living from one-off gigs. If the company changes its model or rules, a "provider" has little recourse. It's a survival game. ${ }^{14}$ 
We have to keep in mind, therefore, that the politics of the last three decades aimed not only at the privatization of public services and benefits but the privatization and individuation of risk. Both shifts rested on the tenets that markets more effectively distribute resources, that regulations impede flexible adaptation and innovation, and so individuals should see themselves as consumers whose needs can be met through private markets and the family. Individuals should work, save, compete, and embrace "personal responsibility" for one's own education, housing, medical care, safety, disability, and long-term security. Although plenty of Americans lived a reality that hardly matched these claims, the fantasy and powerful hold of the ideology tenaciously hung on. The privatization agenda from Reagan to Trump "would have each of us pay for the specific services we can afford rather than establishing a baseline of democratic rights that are available to all regardless of their ability to pay," argues Donald Cohen. ${ }^{15}$ And, the fact is, we have an economy and political culture that has long been based on and accepted shifting or offloading risk onto others: onto slaves, immigrants, women.

Then came COVID-19, a once-in-a-century pandemic. The COVID-19 pandemic impelled into bold relief the stubborn fact that risk is social as well as individual. For the privatization of risk had left the American population in a distinctively vulnerable position to meet the major social crisis of a new pathogen, as a generation of marketization brought us lead-poisoned and chemicalpoisoned water, dismantled public health systems, delayed routine medical care, degraded schools and housing, and overcrowded prisons. It even left us bereft of the ability to act and argue for a common public good or public interest. ${ }^{16}$ Unchecked racist violence, economic insecurity, and a rapidly-spread contagious disease have driven back to the surface the question of how we will socially manage risk. We need an elemental restructuring of employment around new conceptions of time and we need to socialize risk and democratize power.

\section{American work at the turn of the twenty-first century}

One of the chief ways in which workers have been denied the rights of freedom of speech, freedom of assembly, legal protection, and security is to deny the work they do recognition as "real work." Lawmakers, politicians, judges, and conservative pundits and think tanks, for example, persistently deny that home-health aides and personal attendants are a modern, global service workforce and the linchpin of long-term care in the United States. Workers who perform intimate daily tasks for the elderly and persons with disabilitiesbathing bodies, putting on clothes, cooking meals, doing laundry - get mischaracterized as "just moms" or daughters who perform such labors out of duty and love. Many of them also work part-time hours as aides in nursing homes or residential facilities for the disabled. In each spatial setting, the service labor they provide carries out the on-the-ground work of the state, caring for people who receive state benefits or subsidies in some form. Law and ideology, however, perpetuate the notion that emptying bedpans and producing humane conditions 
for living are not the labors that drive the economy. Surely the labor of those who bend steel and scale buildings are more important. Instead of hazard pay, workers' incur a wage penalty, owing to feminization and racialization of the tasks, the work site, and historical legacies of servitude and slavery. While these have been the fastest growing jobs in the economy of the twenty-first century, regardless of the overall booms and busts of the US economy, care workers have had to struggle continuously for inclusion in labor rights and labor standards. ${ }^{17}$

Over the last two decades the stigmatization of a whole workforce and its labor spiraled out to ensnare public workers. The size and scope of the government workforce that carries out public services grew substantially in the United States from the 1950s through the 1970s, and then for the most part, held steady through the turn of the twenty-first century. In 2009, it actually stood at 1 percent higher than it had prior to the period of conservative Republican ascendance. ${ }^{18}$ State and local governments employed over 16,000,000 million fulltime workers; at the end of 2017 that number, including federal employees, stood at 22,341,000. California's local and state workforces had grown to $880,000 .^{19}$ They became political targets of vitriolic rhetorical, ideological, and legal attacks. Governors Scott Walker and Chris Christie deploy typical conservative anti-unionism but also draw from the deep wells of racialized and gendered disdain for the work itself and those who do it-which they willfully brandish as tainted by associations of dependency and nonproductivity. ${ }^{20}$

The burgeoning public sectors, especially at the state and local level, in fact were filled by women and people of color. African Americans had long been concentrated in public sanitation, custodial, and parks jobs, and women had been filling the ranks of teachers. But, with the Great Society programs of the 1960s, women, African Americans, and Latinos moved into an array of semiskilled and skilled jobs, semi-professional and professional occupations, notably in social and human services. The most effective gains from the War on Poverty of the 1960 s were realized by those who secured public jobs. It also sparked new opportunities for union organizing by formerly invisible, marginalized, and low-paid workers, from sanitation workers and social workers to teachers, hospital workers, and police. This upsurge became a continuous wave for the next two, even three decades, upgrading the status of these jobs. With the decimation of unionism in the private sector, public sector unionism became the most dynamic, as well as inclusive segment of the American labor movement. In 2004, 36 percent of all government workers (including 41 percent of all local government workers) in the United States were union members, contrasted to only 7.9 percent of private sector workers. Public sector workers in the United States are roughly four times as likely to be union members today as their private sector brothers and sisters. ${ }^{21}$

Beyond simply the clout of numbers, unionized public sector workers have had the coherence to act politically: to fight for the public social budget, to mobilize support for it or against cuts, and to bring together allies around essential programs. They are not only the implementers and enforcers of the regulatory 
and welfare state, they are its political advocates. Thus, antiwelfare state conservatives, unable to fully dismantle the service state, aimed to dehumanize the service workers, representing them as leeches and parasites. ${ }^{22}$

The eight-hour work day and standard work day were further eroded by the proliferation of "just-in-time scheduling" software that predicts consumer demand and allegedly matches hours to busy and slow periods. For workers, this mode of scheduling means unpredictable shifts, last-minute changes, unstable and insufficient hours, and short-notice cancellations leaving them with no pay. Employees are expected to be on call at all times but accommodate being sent home when "not needed" and therefore not paid. Erratic scheduling has become standard practice in retail, restaurants, and hospitality - the largest employing sectors in the nation. The retail industry in Los Angeles employs about 182,000 workers. A 2017 survey by the UCLA Labor Center and LAANE found that 8 out of 10 workers do not have a set schedule from week to week, and 77 percent get less than a week's notice of their schedule. ${ }^{23}$ In Philadelphia, which has the highest poverty rate in the United States, more than 60 percent of service workers report irregular schedules. A disproportionate share of these workers are African American and female. ${ }^{24}$

Transformation of the health care sector, in particular from a nonprofit to aggressively for-profit, competitive industry has been another major source of work degradation. From the 1980s and 1990s into the early twenty-first century, health care restructuring relied integrally on downsizing the workforce at a given institution, understaffing, and squeezing more labor out of fewer employees - the latter masked as "multiskilling" by management consultants and training programs. "Managed care," writes historian Jean-Christian Vinel, "is precisely designed to force a reduced number of nurses to care for a larger number of patients who are likelier to have serious conditions." More pointedly, managed care companies "directly aimed at the size of nursing staffs because nurses constitute the largest component of the workforce in what remains a labor-intensive industry..."As with retail, hospitals turned to management consultants and scheduling algorithms that broke down labor tasks, estimated time per task, predicted labor hours "needed," and drew up efficient staff scheduling plans. ${ }^{25}$ Such Taylorization did what it has always done: reduced worker autonomy, sped up the pace of work, left less time for recuperation, and shifted the burdens of restructuring onto workers. Mostly, those working in health care settings experienced it as "organizational dysfunction." From week to week, nursing staff could face not enough hours or compulsory overtime. Training and education programs, Ariel Ducey found in her study of New York City's largest employer, the health care sector, "reveal how individual health care workers are pressured to compensate for the irrationalities of America's 'system"" and pro-market policy. The managerial and economic strategies of health care amounted to "an unequal obligation to continually work more."26

Managed care hedged risk for investors but heightened risk exposure for workers. Following a decade of mergers, corporate takeovers, and conversions of nonprofit health centers, hospitals, and nursing homes, those employees 
(nurses, technicians, therapists, counselors, aides) were already voicing complaints in the late 1990s, specifically regarding insufficient staffing, overly stressful working conditions, lack of support or safety equipment, and low pay. A decade later, statistics show, nurses faced an occupational injury and illness rate double that of workers in all private-sector industries. Nursing assistants experience exceptionally high rates of occupational injury, whether working in residential care facilities, assisted living facilities, continuing care facilities, nursing homes, hospitals, group homes, or private homes. In fact, occupational injury rates for direct care workers are among the highest in the country, owing to lifting and moving patients, various events on the job, overexertion, inadequate staffing and exposure to violence. Yet two thirds of these 4.5 million workers have no paid leave and therefore have little time for self-care or recuperation. The insecurity of the job and managerial culture discourage care workers from reporting injuries. ${ }^{27}$

COVID-19, therefore, is also the crisis of the full-throttle marketization and corporate consolidation of American health care. The American marketdriven, for-profit health care system and private insurance system are based upon denial of care. Gatekeeping, co-pays and ever larger deductibles, refusal to cover pre-existing conditions, and dropping high-risk individuals - or covering only fully healthy ones-ensure higher revenues or profits and are considered legitimate forms of "risk management." The bodily insecurity of Americans in low-paying jobs and unstable labor markets and those whose connection to wage work is tenuous is perpetuated by this so-called risk management; it creates the imperative of a constant hustle. Work has left them, as fast food workers put it, "just sick and tired of being sick and tired." 28

Annelise Orleck's 2018 book, We're All Fast Food Workers Now, a global investigation of low-wage worker uprisings, shows that from back-to-back shifts to walking home late at night after work to poisons, toxins, and burns on the job, "danger is still a daily reality for workers" in the United States and around the world. Notably, police murders of Black people have taken place outside fast food restaurants (Rayshard Brooks and George Floyd) and 7-Elevens (Treyvon Martin). Whether in the Philippines, Bangladesh, Brazil, or the United States, worker demands converged: "Regular employment, 8hour day, . . . Just Wages, Safe Workplace." 29 This is the world the virus burrowed into and took over, swiftly breaking us down cell by cell.

\section{Class}

We've heard plenty of post-mortems for "the working class" - allegedly owing to technological change, politics, or culture-but, in one of the most remarkable and stark cultural shifts in response to the COVID-19 pandemic, the working class became visible and recognizably important as a class. A panoply of service and logistics jobs-blue-collar, pink-collar, white-collar, semi-professional, and professional-of connecting and keeping people alive have been, in an unprecedented way, bundled and represented together. Across race, 
gender, and ethnicity, those performing such jobs became "frontline workers" and "essential workers." It's been fascinating to see so cogently the claim of the National Domestic Workers Alliance, "we do the work that makes all other work possible."

Corporations couldn't rush fast enough to get commercials into production that offered paeans and salutes to "front-line workers" and "essential workers." Burnished and wistful, with swelling music, the camera focuses in on a montage of working-class jobs: warehouse workers, hospital nurses and aides, postal deliverers, pickers and packers in fields, cashiers and supermarket workers, bus drivers and truckers, and food preparers. It was breathtaking how many low-wage and exploitative employers spent big money for television commercials, full-page newspaper ads, social media ads, and outdoor billboards or electronic signs to explicitly praise the working class. Walmart, Amazon, Dunkin', Uber, Dove (soaps and beauty care products), FedEx, Hefty, Budweiser, Oakland International Airport, and fast food companies aired prime time ads of gratitude. McDonalds even pledged to give frontline workers free sodasplus for its own workers, a whole week's worth of "Thank you meals."

On the one hand, I think it's worth registering the positive. It's been decades since we've seen public culture acknowledge the essential contributions of a diverse and extensive working class and take seriously the central economic role that service workers, food chain workers, and care workers perform in holding together our society. Highlighting the work of African Americans, women, and immigrants, it has valorized the labors that keep us alive, transport us, bring us our consumer goods, food, and basic necessities, and even connect us to our common human experiences. Nor did such recognition simply take the form of symbolic, nostalgic masculinity that often gets trotted out and flexed at election time. Millions more Americans work in health care or in retail or in logistics than in auto or steel manufacturing combined. There are twice as many home health aides. The retail industry is the largest employer in the United States. According to the National Retail Federation, ${ }^{30}$ retail supports one in four US jobs, or 42 million working Americans. In 2018, health care, retail trade, and state and local government were three of the top five employing sectors. ${ }^{31}$ It finally became culturally visible and meaningful that they stand at the center rather than the margins of the American economy.

On the other hand, these paeans did not mark any shift in power. Indeed, it could be argued these tributes - meant to hit emotional registers - were made specifically to head off any shift in power. They emphasized "self-sacrifice"as if to say low-wage service workers, especially women and people of color, should be prepared to sacrifice themselves for others. The rush to post public salutes to front-line workers can be seen as a class action by corporate elites, a class strategy to muffle workers' voices in a gauzy haze of charitable impulses and service. Such corporate representations of "frontline work" in the COVID19 era imply that the standardized workday, codified by the New Deal's Fair Labor Standard Act, can and must be stretched, pulled, and unshackled into the open-ended arbitrariness that characterized hospital, nursing home, and 
domestic labor before labor standards. Or pressed into shifting and precarious part-time shifts.

Given the degree to which the pandemic is exposing the structural failures and inequities of market-based care, this corporate propaganda attempts a double shrouding of the class relation. First, the corporate propaganda from health-care companies and hospital-medical chains cloaks the ways in which capitalist elites determine the rules for health care as a profit-maximizing industry with "service to the public" rhetoric that absolves business of the consequences of a managerial and insurance strategy based fundamentally on the denial of care, making the crisis of COVID-19 utterly unmanageable. Second, it deflects the fact that inordinate class power exercised by corporations and employing institutions had placed these workers in such harmful positions for years leading up to this moment. Particularly ironic were tribute ads from Hefty, since direct-care workers lacking PPE had to turn to using large plastic garbage bags to protect their bodies. ${ }^{32}$

There is another way in which class has become visible and salient. What has been revealed about being an essential worker or being labeled as such by opportunistic employers is the inability to say "no." Being essential meant risk of exposure to health and bodily threats was bound up with risk of exposure to economic insecurity. Whether working without adequate protection, feeling ill, or having inadequate information on virus cases in one's work place, we've been hearing from people across the economic spectrum who had to report for work. The threat could be explicit or internalized, immediate cash flow need or impending financial insecurity, but refusal is not an option and the stakes of trade-offs are too high. Class power and class struggle have also been palpable insofar there are companies that have the political as well as economic weight to claim their production process and profit stream as essential, even if it meant using replacement workers or subcontracted workers to do the labor of its allegedly essential workers.

If we think of class as a process, class is defined by "the practices and relations within which [consent, exploitation, and domination] are secured, created, and challenged," writes political theorist Kathi Weeks. Amid the pandemic, who works and who doesn't, or who works in a safe or unsafe place, lays bare the "the relationship of domination and submission that is authorized by the waged labor contract and that shapes labor's exercise." 33 The compulsions of market labor have become publicly clear again; pandemic conditions have, however brief the moment may be, punctured the ideological obfuscations that markets are the very source of liberation, opportunity, and autonomy. With every person who has said I felt sick, but I had to go to work; I felt at risk but I couldn't afford to lose my job; I had to take care of someone else, but I had no paid leave-we see how much contemporary work has become associated with unfreedom. They know they are dispensable, the power arrangements of work make that clear. But now that has become clear as a class processthrough extensive media attention and political attention. The managerial response to COVID-19 ratcheted up management's ability to compel those in 
their employ to work continuously. Unfortunately, political officials never thought to compel employers to see a different employment policy as a rational response to pandemic: rotational schedule (without loss of pay) that would promote safety, distancing, and recuperation. For example, why not assign three days on, three days off, to allow recuperation and reduction of risk exposure? Why can't we talk about a rearrangement of work time that would recognize risk as social?

"The practices and relations within which [consent, exploitation, and domination] are secured" simultaneously pierced the veil regarding policing and the suppression of Black people's freedom of movement, freedom of speech and assembly, autonomy, and physical bodily integrity. Essential workers, who know how much the company manipulates their dispensability and insecurity, recognized themselves and the processes of command and control, disregard and devaluation among the targets of police racial violence. Amazon workers had already been staging nationally coordinated walk-outs over safety conditions and the lack of protection and workplace information in relation to COVID-19. Adrienne Williams, an Amazon driver and leader of Bay Area Amazonians, said "I realized that Amazon doesn't give a crap . . . here's this place where people are getting hurt or dying . . . They're bullies - and I am so not about being bullied." 34 They extended their labor resistance and walked out for Black Lives Matter. The next day, Williams said, she turned on the television. "The first thing I saw: 'Black Lives Matter. Amazon Stands in Solidarity with the Black Community' [ad]." She responded, "If Amazon really stood in solidarity with the black community, they wouldn't pay us slave wages. They wouldn't retaliate against us for speaking up when people's bodies are in danger. What a crock of shit." 35

Yet another facet of capitalist class political power of the state has impeded workers' attempts at self-protection during the pandemic. Prior to the onset of the pandemic, the Occupational Safety and Health Administration (OSHA), under the Trump Administration, had "the lowest number of on-site inspectors in the last 45 years." Despite Harvard Business School, UC-Berkeley Business School, and Rand Corporation independently concurring that OSHA inspection programs resulted in substantially fewer injuries and occupational illnesses, OSHA staffing levels declined continuously during the Trump years, with at least five thousand fewer employees than under the Obama or Bush Administrations, and key positions, such as director of enforcement and regional directors, have been left vacant. ${ }^{36}$ Consequently, workers in American workplaces already labored in health-compromising environments structured by imbalances of the power.

This accumulated, long-term disregard for workers' health and safety on the job merged with the government's hands-off approach to virus containment. According to the National Employment Law Project, "OSHA has completely abdicated its responsibility to ensure that employers keep workers safe on the job." Although thousands of complaints and grievances had been submitted to the agency by late April 2020, "OSHA has not issued any enforceable 
COVID-19-specific requirements, practices or policies that employers must implement to protect workers." Nor is OSHA conducting COVID-specific onsite inspections. Mostly, the agency is dismissing whistleblower complaints. ${ }^{37}$

So, this brings us to the question: Do workers have economic rights when we come up against a crisis of need? How, then, can this newly cohered and recognized working-class act collectively, especially since single-actor whistleblowers are subverted? What is the bridge from recognition to collective action to system-changing power?

\section{Labor and collective action}

The abuse of workers and the abuse of Black people by police have provoked walkouts and wildcat strikes across a surprising array of occupations. Teachers, physician residents, hospitality workers, auto workers, grocery workers, apple pickers, librarians, and university staff have engaged in work stoppages, ranging from the eight minutes George Floyd suffocated with a policeman's knee on his neck to open-ended refusals to work under existing conditions. Work refusals among bus drivers were sparked when Detroit bus drivers struck in Detroit on March 17; as a result, they won demands for PPE, extra cleaning, riders using the rear doors, and an end to fare collection. Bus drivers in a number of other states subsequently followed suit. Nurses have engaged not just in local walkouts but in nationally coordinated labor actions, under the banner "PPE Over Profit." Included in their demands were "nationalizing the health care-medical industry" and universal health insurance. Labor journalist Jane Slaughter reported that "National Nurses United went to Washington, D.C. May 5 with an 'empty shoes' protest, demanding that President Trump use the Defense Production Act to order mass production of PPE, ventilators, and test kits. They lined a sidewalk with white nurses shoes to commemorate 88 fallen coworkers.. ${ }^{38}$ GE workers in Massachusetts, Virginia, Texas, and New York coordinated protests to demand GE switch to ventilator production, rather than shutdowns and layoffs. ${ }^{39}$

Since the 1980s, formally called strikes by unions had been disappearing from American economic life. But the COVID-19 pandemic actions emerged from a different well-spring. One forerunner is the effervescence of organizing among poor, Black, Latinx, and immigrant women from the 1960s-1980s: domestic workers' movements, farm worker unionism, public sector unionism, ACORN, and workers' centers. These led to new labor organizing strategies, unions, and collectives among those who had been on the margins, such as home-care workers, childcare workers, taxi drivers, custodians, and day laborers. The other antecedent is the direct action, take-it-to-the-streets mobilizations of the last decade: the Fight for $\$ 15$ campaigns among fast-food workers and warehouse workers, Our Walmart and its Black Friday walk-outs and pickets, Action Now in Chicago, OnePA in Philadelphia, LAANE (Los Angeles Alliance for a New Economy), City Life/Vida Urbana in Boston, Ain't I a Woman?! in NY, and Black Lives Matter. Through these groups, working-class folks took to 
the streets, won higher wages, fought housing evictions, and began to change working conditions.

More recently, they've launched the battle to wrest control of time and roll back the control of working-people's lives held by the employing class. Since 2017, this effort has taken the form of Fair Workweek campaigns, which aim to pass local ordinances that establish workers' rights over scheduling. A Fair Workweek Ordinance includes fourteen days notice of worker's schedule, the right to ten hours rest between shifts, ability to request schedule change or refuse changes without retaliation, option to obtain full-time hours before an employer hires more workers. Philadelphia, Chicago, and Seattle enacted ordinances. The struggle to pass the ordinance in Los Angeles has been waged for two years. Thus, even prior to COVID-19, the Fair Workweek movement connected class stress, health problems, lack of leisure time, lack of sleep, and inability to plan or sustain education, care responsibilities, or life sustaining activities to employer manipulation of time hitched to disposability. Workers had begun building an offense and a codification of rights around the problem of time. In Kathi Weeks' terms, it asserts 'the refusal of work's domination over the times and spaces of life." 40

The dramatic work stoppages by NBA and WNBA professional athletes in August 2020 are powerful, even if athletes are not among the struggling working-class. They used a labor tactic and their considerable cultural clout to insist that business as usual could not continue under conditions of racist violence. The fact that they could pull it off and win political objectives has symbolic value in boosting the confidence of others to engage in refusal. Union locals representing a cross-section of service and industry workers (locals of SEIU, UNITE HERE, AFSCME, UE, UFCW, and a number of teachers unions) issued a public solidarity statement that connected Black Lives Matter and working-class struggle: "They remind us that when we strike to withhold our labor, we have the power to bring an unjust status quo to a grinding halt. The status quo- of police killing Black people, of armed white nationalists killing demonstrators, of millions sick and increasingly desperate-is clearly unjust and it cannot continue." 41

We've had a pandemic year of walk-outs, mass marches, wildcats, and local and state hours initiatives. Wildcats, of course, are ephemeral and episodic. What will give this upheaval sticking power? That question comes back to institutions and how institutions educate and prepare people for long-term fights and power-building. To begin with, unions have to be nimble in their tactics, insistent on their possession of the fundamental rights of freedom of association and speech, broad in their issues, and ready to act in coalition with non-unionized people. Instead of "training" consisting of preparing workers for the Taylorized speed-ups set by management, new labor approaches to training now teach workers it's within their rights to fight when terms and conditions seem to be violated. SEIU 1199 New England home-care officials explained they are retraining organizers and stewards on how to lead a shop fight - to take on coercive bosses, to demand timely fair payment, to fight for consistency 
in hours, to fight when due process is denied. The goal is "concerted training" explicitly "to build a fighting organization," affirms Norma Martinez-HoSang, an organizer for both Oregon's public-sector SEIU Local 503 and 1199 New England's Home Care Division. SEIU 1199 New England (1199 NE) has taken an additional step by creating rank and file workers' education sessions and the Home Care Leadership Academy. "We want workers to understand where their power comes from," says Puya Gerami, 1199 NE Education Director. They're no longer speaking the ameliorative language of the AFLCIO about protecting the "middle class" and "the middle-class pay check." This is now about the ruling class versus the working class. "We're building an organization that can take on the power of the ruling class," as Gerami puts it. They also aim to build a solidarity economy. Political education combines units on labor history, structural racism, intersectionality, the legislative process, and the mechanisms of economic inequality; it also includes building political skills among members. ${ }^{42}$ SEIU, UNITE HERE, and the UE have implemented these principles and programs. The success of the Chicago Teachers Union and United Teachers Los Angeles strikes followed a decade of rank-and-file groundwork for engagement.

The pandemic has reminded us that not everyone works-either because they cannot or because they've been let go or fired. And the great majority of Americans are outside unions and work under "at-will" terms. That means the bridge to the solidarity economy must be built by a range of organizations and collective associations. Starting from within unions, the Bargaining for the Common Good is one strategy. Bargaining for the Common Good aims to leverage union bargaining and strike capacity into contracts that include community priorities: education, housing, health care access, and racial justice and equity. "Campaigns must deeply engage memberships of both unions and community organizations...[with] joint visioning between members of the different organizations." Taking the offense requires directly challenging the agents extracting resources from communities and perpetuating repression, from banks to corporations to police. LAANE is a different entity but committed to building a new economy and democracy through grass-roots organizing and community-oriented policy. Branching out from an living wage and worker retention ordinances to "Community Benefits" Agreements that tie city development to specific protections and benefits for communities, LAANE has become a leading partner in campaigns for immigrants' rights, water access, environmental protection and elimination of toxicity from working-class communities, green jobs, and Fair Workweek ordinances. Each of their campaigns (e.g., Wages and Economic Development; Education; Energy and Water) is rooted in an alliance with community groups, unions, racial justice organizations, student groups, and other worker organizations. Taxing the rich and redistributing wealth is an explicit demand of both movements. They've been scaling up by forging national organizations, but national organizations that stay rooted in local mobilization and local community power. LAANE is a co-founder of the national Partnership for Working Families. The Bargaining for the 
Common Good Network is now mapping a national index of union contracts and expiration dates to sync campaigns and strikes more broadly - to change the temporalities of previously fragmented and localized collective bargaining contracts and use them to leverage power. It's taken a generation to revive the notion that there is a common good, we can put racial and gender justice at the center of it, we can take back the wealth elites have stolen, we can reclaim public space, and we must recommit to social and physical infrastructures that will keep us alive as we face unprecedented pathogens, extreme weather events, water and food shortages, the right of people to move and migrate, and the ability to claim a distinction between work time and nonwork time. ${ }^{43}$

Americans have been asked to pin their hopes for the future on two improbable outcomes: the return of a heyday of manufacturing jobs or the vast expansion of service jobs. Neither will happen, nor on their own would they provide any change in the insecurity, hazards, or hierarchal power relations of work. We've entered a stage in which large-scale, oligopolistic capitalism needs far fewer workers. It's not just steel, auto, and electronics factories that have mechanized. Anything with a check-in or check-out counter just needs a kiosk or touch screen: supermarkets, parking garages, airlines, hotels, leisure/ entertainment venues. Food packing is done by robots. Distribution centers have rovers that identify, pick up, and load. Even Uber, with its push to use "self-driving cars," is now seeking to displace drivers who were already displaced workers, expunged from other sectors of the economy. In fact, this process has only been sped up by the pandemic conditions and the need for social distancing: check-in and payment for salons, dental offices, and medical centers is done on-line without any need for person-to-person interaction. We should also wonder what will result after a year's worth of online primary, secondary, and higher education.

The class challenge to the economic and political elite must mount a new set of demands and on different terrain, not a fight to return to how we worked before COVID-19. Work, nonwork, and investment should be seen together in collective terms, as care workers' activism has long suggested. We should envision policies that create work sharing and sustainability with less work-defining human life not subordinate to work. The politics of time must be linked to feminist re-imaginings family life, family care, and community care. The solidarity economy is a local economy that defends its public spaces without surveillance, reclaims its public services, builds community wealth by supporting worker and resident-owned and -directed enterprises, enhances people's capabilities at whatever level of physical or cognitive ability, and builds new avenues for resident participation in democratic social and economic development. Then we maybe we could all breathe and flourish. New conceptions of time may also enable us to break free of the obstinately rapacious imperative of economic growth and grasp the temporal responsibilities we owe to a sustainable earth. 


\section{NOTES}

1. The New York Times, June 29, 2020, "Three Words. 70 Cases. The Tragic History of 'I Can't Breathe'."

2. “Ain't I a Woman!?” Fall 2018 Newsletter; “Ain't I a Woman?!” Fall 2019 Newsletter; JoAnn Lum, Letter to Supporters, Ain't I a Woman Campaign, October 20, 2019; Correspondence, JoAnn Lum to Jennifer Klein, May 5, 2020, email in author's possession. Justa Barrios tells her story in a video: https://www.facebook.com/aiwcampaign/videos/vl. $553962795446075 / 442318980043584 /$ type $=1$.

3. The New York Times, June 30, 2020, "When You Are Paid 13 Hours for a 24-Hour Shift," E. Tammy Kim. https://www.nytimes.com/2020/06/30/opinion/coronavirus-nursing-homes. html.

4. The New York Times, August 30, 2020, "Breonna Taylor's Life Was Changing. Then The Police Came to Her Door," Rukimini Callimachi.

5. Lawrence Glickman, A Living Wage: American Workers and the Making of a Consumer Society (Ithica, NY, 1997); Lara Vapneck, Breadwinners: Working Women and Economic Independence 1865-1920 (Urbana-Champagne, IL, 2009); Tobias Higbie, Labor's Mind: A History of Working-Class Intellectual Life (Urbana-Champagne, IL, 2019).

6. Jennifer Klein, For All These Rights: Business, Labor, and the Shaping of America's Public-Private Welfare State (Princeton, NJ, 2003).

7. Dorothy Sue Cobble, The Other Women's Movement: Workplace Justice and Social Rights in Modern America (Princeton, NJ, 2004), 139-41.

8. Erin Hatton, The Temp Economy: From Kelly Girls to Permatemps (Philadelphia, PA, 2011), 12-6; 74-6.

9. David Weil, The Fissured Workplace: Why Work Became So Bad for So Many and What Can Be Done to Improve It (Cambridge, MA, 2014; 2017), 8-9.

10. Hatton, The Temp Economy, 107.

11. Tom Juravich, At the Altar of the Bottom Line: The Degradation of Work in the $21^{\text {st }}$ Century (Amherst and Boston, MA, 2009), 3, 5-8.

12. Weil, 3, 10.

13. Hugh Baran, "Forced Arbitration Enabled Employers to Steal $\$ 12.6$ Billion From Workers in Low-Paid Jobs in 2019," National Employment Law Project Data Brief, February 2020, https://nelp.org/s27147.pcdn.co/wp-content/uploads. 59.1 precent of Black workers and 57.6 percent of women workers, 54.3 percent of Hispanic workers are subject to forced arbitration. Class/collective action waivers are routinely included, which "prevent employees from banding together with colleagues to challenge their employer lawbreaking, whether in court or arbitration."; National Employment Law Project, "A State Agenda for America's Workers: 18 Ways to Promote Good Jobs in the States," December 2, 2018, https://www.nelp. org/publication/state-agenda-americas-workers-18-ways-promote-good-jobs-states/.

14. The New York Times, August 16, 2014, "In the Sharing Economy, Workers Find Both Freedom and Uncertainty," Natasha Singer.

15. Donald Cohen, "Privatization--Chipping Away At Government." In Labor in the Time of Trump, edited by Jasmine Kerrissey, Eve Weinbaum et al. (Ithica, NY, 2019), 107.

16. Cohen, 108-15.

17. Eileen Boris and Jennifer Klein, Caring for America: Home Health Workers in the Shadow of the Welfare State (Oxford, 2012); Employment of home health aides and personal care aides is projected to grow 36 percent from 2018 to 2028, much faster than the average for all occupations. On wage penalty, see Paula England and Nancy Folbre, "The Cost of Caring," Annals of the American Academy of Political and Social Science 561, 1 (Jan. 1999): $39-51$.

18. Jake Rosenfeld, What Unions No Longer Do (Cambridge, MA, 2014), 42-3.

19. "State and Local Government Employment: Monthly Data," Governing, August 5, 2018. http://www.governing.com/gov-data/public-workforce-salaries/states-most-governmentworkers-public-employees-by-job-type.html.

20. Klein, "What Wisconsin Was Really About," Democracy, May 10, 2011. https:// democracyjournal.org/arguments/what-wisconsin-was-really-about/.

21. Joseph A. McCartin, "Bringing the State's Workers In: Time to Rectify an Imbalanced U.S. Labor Historiography," Labor History 47, 7 (2006). 
22. Daniel HoSang and Joseph Lowndes, "Parasites of Government: Racial Antistatism and Representations of Public Employees amid the Great Recession," America Quarterly, 68(4): 931-954.

23. Fair Workweek LA, "Hour Crisis: Unstable Schedules in the Los Angeles Retail Sector," fairworkweekla.org@fairworkweekla; Los Angeles Times, March 14, 2018, "Erratic Schedules a Part of Life for L.A. Retail Workers," Andrew Khouri.

24. Center for Popular Democracy, Fair Workweek Initiative, and One PA, "Certain Uncertainty: Low Wages and Unpredictable Hours Keep Philadelphia Hourly Workers in Poverty, Data Brief, October 2017, http://static1.squarespace.com.static; Michaela Winberg, "City Council Might Set Regular Hours for Every McDonald's Employee in Philly," October 10, 218, BILLY PENN, billypenn.com. $216-20$.

25. Jean-Christian Vinel, The Employee: A Political History (Philadelphia, PA, 2013), 216;

26. Ariel Ducey, Never Good Enough: Health Care Workers and the False Promise of Job Training (Ithica, NY, 2009), 6-7.

27. Stephen Campbell, "Workplace Injuries and the Direct Workforce," PHI Issue Brief, April 2018, https://phinational.org/wp-content/uploads/2018/04/Workplace-injuries-and-DCW.

28. Annelise Orleck, We're All Fast Food Workers Now: The Global Uprising Against Poverty Wages (Boston, 2018), 34-5.

29. Orleck, 24.

30. https://www.investopedia.com/terms/n/national-retail-federation-nrf.asp.

31. https://nrf.com/insights/economy/about-retail-jobs; U.S. Bureau of Labor Statistics, Employment by Major Sector, 2009-2019" September 1, 2020, https://www.bls.gov/emp/ tables/employment-by-major-industry-sector.htm.

32. Chris Brooks, "Using Trash Bags for Gowns," Labor Notes, March 30, 2020.

33. Kathi Weeks, The Problem with Work: Feminism, Marxism, Antiwork Politics, and Postwork Imaginaries (Durham, NC, 2011), 19-21.

34. Rosa Astra, "Bay Area Amazon Workers Fight for Safe Working Conditions: Interview with Adrienne Williams," July 30, 2020, Liberation, liberationnews.org.

35. Paul Bowd and Mary Jirmanus Saba, "Amazon, FedEx Workers Fought Exploitation in a Pandemic, Then Joined An Uprising," The Intercept, July 15, 2020, https://theintercept.com/ 2020/07/15/amazon-fedex-essential-workers-coronavirus-blm-protests/. See also video interview clip of Williams, filmed and posted by Saba.

36. National Employment Law Project, "Worker Safety in Crisis: The Cost of a Weakened OSHA," Data Brief, April 2020, www.nelp.org//s27147.pcdn.co.

37. Ibid.

38. https://thehill.com/policy/healthcare/496730-nurses-protest-for-ppe-outside-white-houseyou-throw-us-to-the-wolves.

39. Jane Slaughter, "Finding New and Old Ways to Fight New and Old Foes," Labor Notes, May 26, 2020.

40. Weeks, The Problem with Work, 124; 13.

41. Statement From the Labor Movement in Support of Work Stoppages for Black Lives," August 31, 2020, https://www.laborforblacklives.org/statement/statement-from-labor-movementin-support-of-work-stoppages-for-black-lives-english.

42. Norma Martinez-HoSang Interview by Author, February 26, 2018, New Haven, CT. In September 2020, Norma Martinez-HoSang became Common Good Project Director, SEIU Connecticut State Council. Puya Gerami Interview by Author, February 21, 2018, New Haven, CT.

43. http://bargainingforthecommongood.org; http://LAANE.org. 